\title{
Specifics of Forming the Competitive Hotel Complex in the Kaliningrad Region of Russia
}

\author{
Valentin Korneevets ${ }^{1} \&$ Liudmila Semenova ${ }^{1}$ \\ ${ }^{1}$ Immanuel Kant Baltic Federal University, A. Nevskogo, 14, 236041, Kaliningrad, Russia \\ Correspondence: Liudmila Semenova, Immanuel Kant Baltic Federal University, A. Nevskogo, 14, 236041, \\ Kaliningrad, Russia. E-mail: 1semenova@kantiana.ru
}

Received: October 14, 2014

doi:10.5539/ass.v11n3p289

\author{
Accepted: October 21, 2014 Online Published: December 30, 2014 \\ URL: http://dx.doi.org/10.5539/ass.v11n3p289
}

\begin{abstract}
Modern tourists field and its effective development do not rely just on existing infrastructure, but also on the condition of the competitive landscape in the region. In this article under review come theoretical aspects of forming the regional hotel complex through the example of exclave Kaliningrad region. Key factors and specifics of creating competitive advantages are analyzed. Future hosting of the world cup 2018 can also attribute to the increase of competitiveness in the hospitality industry and it should be considered in the development of the regional strategy for the regional hospitality industry.
\end{abstract}

Keywords: competitiveness, regional hotel complex, Kaliningrad region, regional development strategy

Forming a competitive hotel complex as a part of hospitality industry is a high priority and strategic goal for Kaliningrad region. If achieved, it allows to create new jobs, to spur development of the regional economy, while saving and making an efficient use of touristic and recreational potential, cultural and historic heritage.

\section{Theoretical Aspects of Forming the Competitive Regional Hotel Complex}

\subsection{Theoretical Basis for the Development of Competitiveness of Tourist Areas}

In scientific literature competitiveness issues are devoted a considerable attention. One of the first russian studies in which competitiveness is comprehensively analyzed is a monograph by M.G. Dolinskaya and I.A. Solovyev. It is regarded in comparison with another important element - quality of production. (Dolinskaya, 1991). Another researcher P. Zayavlov adjects to that quality evaluation, quantity evaluation of economic entities with competitiveness characteristics. (Zavyalov, 1995).

It should be noted, that competitiveness is a dynamic category, and first of all dynamics is driven by controllable from outside, exogenous factors.

Taking to the consideration the evolution of scientific approaches and principles in the management theory of the competition and competitiveness it should be noted that in the market economy the base of leading position is a proper support and guarantee of existing competitive advantages. The datum line for theory of competitive advantages is a thesis, that any country with the same level of economic development has a certain unique set of competitive advantages. Explicating theory of A.Smith (Smith, 1992) D.Ricardo made a conclusion: “... it is economically sound for all countries to participate in the international trade. Even having an absolute advantage in production of certain goods state has the right to deny it and specialize in a more effective production, purchasing these denied goods and services from countries with fewer resources". (Semenova, 2006, p. 24).

This theory is named a theory of comparative advantages. It explains the two-way interchange of tourists products in the international hospitality industry as a result of difference in price between countries. However, this theory doesn't explain reasons of emersion the competitive advantages. This matter was examined by economists E. Heksher and B. Olin, they pointed out the reasons of emersion the competitive advantages difference lies in occurrence of inhomogeneous agents of production (Blaug, 1994). M Porter determines forming on the land a touristic cluster united by common interests as one of the aspects on competitiveness. (Porter, 1990)

Nowadays issues of comparative advantages are devoted a considerable attention. In the words of $\mathrm{M}$. Thatcher "Wealth of the country is not necessarily built on its own natural resources, it is achievable even with their 
complete absence. The most important resource is people. State need only establish a framework for the flourishing of talent people" (Thatcher, 2003, p. 16).

Therefore competitive advantages could be present in different ways, have different levels of hierarchy, be related to the commodity (service), enterprise, industry, economy in whole; be based on priced and non-priced factors; be long-term mid-term and short-term; stable and non-stable; unique and simulated and so on.

\subsection{Development Factors of Competitiveness of Tourism and Hospitality}

Some branches and complexes have distinguishable competitive advantages. For example, hotel enterprise has a more valuable competitive advantage if it has a wider range of services or good location (center of the town, close to points of interest, easy transportation and so on).

Another factor of competitiveness for a subject of the hospitality industry is a repetitive tourists flows, depending upon many factors: level of service, loyalty of local population, the uniqueness of the existing cultural, historical and natural resources. However it should be noted in many industries, especially those, connected to service activities (e.g. hotel sector) competitiveness originates in primary - hotel enterprise. It is evident on the market of hotel services.

To attract tourist flows in a particular regions of the Russian Federation, increase the economic efficiency of development of hotel business it is necessary to study the whole range of external and internal competitive advantages that exist among the participants of the tourist market and forming competitiveness of the industry. This owes to similarity and identity of competitive advantages between organizations in the industry. Internal benefits can include high demand for the service, the high proportion of competitive personnel in the industry, the exclusiveness of the goods (services), etc. External benefits can include a high level of competitiveness of the country, active support of business by state, the openness of the company and markets, high-quality system of training and retraining of managerial staff in the country, the climate and the geographical location of the country, etc.

The hotel sector of a tourist destination has a significant influence, and often plays a leading role in shaping the competitive hotel complex. Despite many common features similar to the tourism industry, for the hospitality industry of the region it is useful to distinguish the following competitive advantages:

- resource (consumer effect from received services associated with the price characteristics; the base for such benefits may be favorable tax and bureaucratic regimes created by the government as part of the hospitality industry development, as well as the advantageous location of the region in the center of tourist flows, the unique natural resources, that creates value of consumption for the hospitality industry in the eyes of consumers, etc.)

- technological (use of mass production technologies, providing economies of scale and increase in customer benefits linked to the price characteristics of the acquired hotel services)

- innovation (formed through the implementation of $R \& D$ results, which allows to increase consumer benefits associated with the attributes of the parameters of the purchased services)

- global (connected with forming non-economic (environmental, social) standards of economic activities and their implementation;)

- cultural (caused by cultural singularity of geographic areas) (Semenova, 2006).

The appropriate level of pricing is determined by the advantages of contributing to the competitiveness of the participants in the hotel market. It should be noted, that in recent years prices of accommodation services in the global hospitality industry are constantly rising. In our opinion, the reasons for this are increase in hotel rating due to renovation and reconstruction, development of the event-tourism market, attracting additional tourist flows in tourist attractive regions. In our opinion among such perspective regions in Russia, the Kaliningrad region could be distinguished.

\section{The State of Tourism and Hotel Complex in the Kaliningrad Region}

\subsection{Available Tourist Resources}

The Kaliningrad region has a unique exclave geopolitical location: it is located in the center of the European continent, bordered by the Republic of Poland and Lithuanian Republic. Natural and climatic conditions (mild climate, sea coast of the Baltic sea), the presence of unique natural objects located on the territory of the Kaliningrad region (unique national Park "Kurshskaya Kosa" (Curonian spit) is included in the list of UNESCO), allow likely to predict a gradual progressive development of tourism in this territory and sustainable competitive position in the tourist market of the Baltic region. 
Among comparative advantages of the Kaliningrad Region, researches distinguish the following (Baltic Status, 2014):

- beneficial geographical location, allowing to attract tourists from Russia and European countries;

- unique natural and ecological, historical, cultural and recreational potential;

- rich historical and cultural heritage of the Kaliningrad region, which combines the east prussian and russian traditions on one particular territory;

- well-developed transportation system

- increase of the tourist industry competitiveness in the Kaliningrad region, through targeted regional policy and integration of the tourist market participants;

- availability of public and commercial organizations for development of tourism in the region

- experience in the international cooperation and long-term projects in hospitality industry and tourism

- use of opportunities of entering into the Federal target program of development of tourism;

- the opportunities to attract foreign and Russian investors for financing the development of tourist infrastructure

Tourism is one of the priority and fast evolving sectors of economy, which has not lost its appeal even after the 2008 crisis. The growth rate of the industry ( $4 \%$ per year) allow to predict a gradual increase in the pace of development, which is given in the table data below (table 1) (The Governor of the Kaliningrad region, 2014) and the resulting polynomial forecast of development (Figure 1).

Table 1. Indicators of the development of tourism in Kaliningrad region 2007-2013

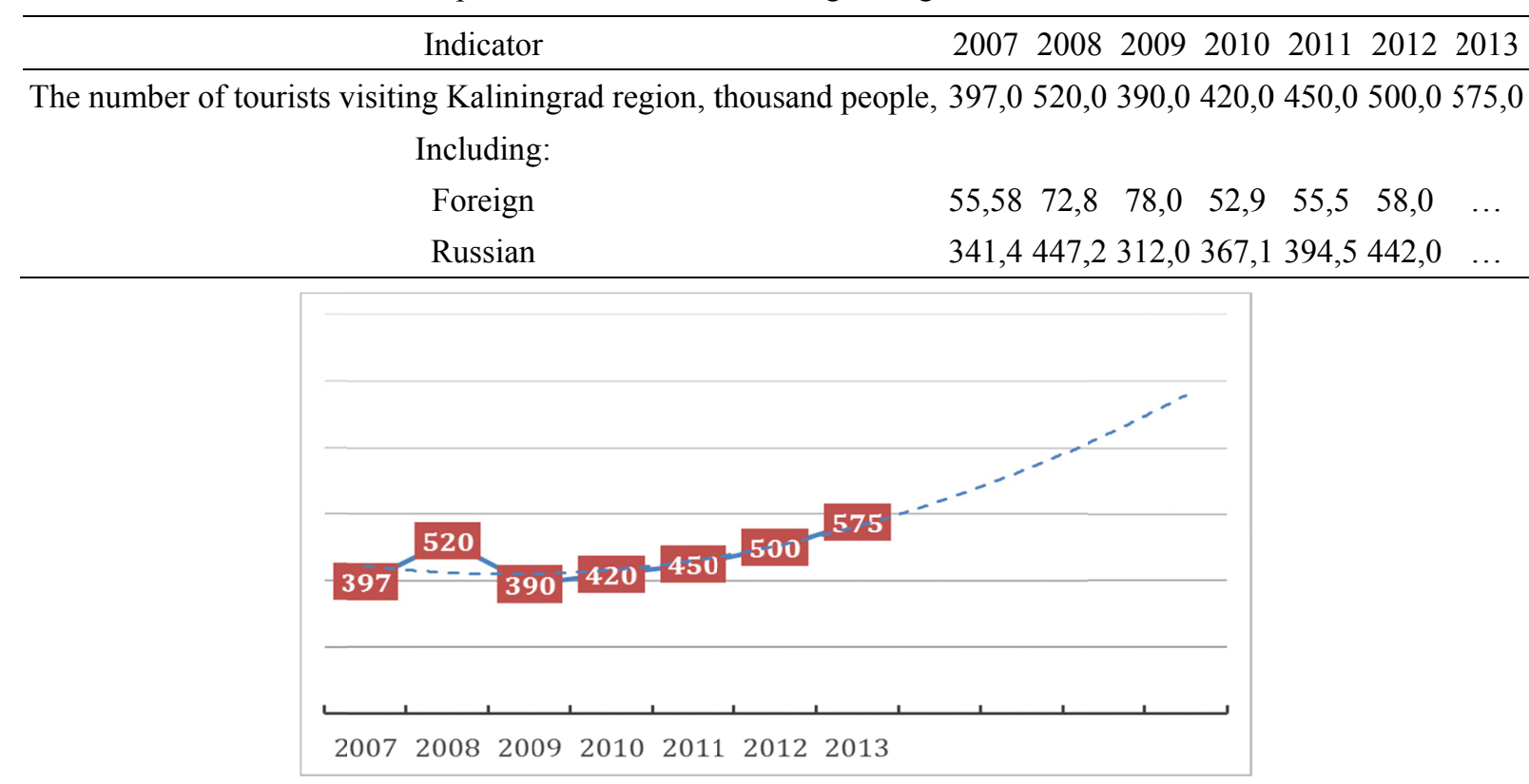

Figure 1. Polynomial forecast of development of tourist industry

\subsection{Geography and Structure of Tourist Flows}

According to official statistics the structure of the tourist flow in the region is dominated by domestic tourists (86\%). Among other visitors representatives of the CIS and EU citizens can be distinguished. Analyzing domestic tourist flows it should be noted that it is dominated by visitors from Moscow $(27,9 \%)$ and St. Petersburg (22,7\%). 13,3\% - residents of Central, 10,4\% - Volga Federal districts. Russian tourists who visit the region with recreational purposes and use the vacation package accounted for $78 \%$ of Russian tourist flow. The second most important segment is foreign tourists, where $50 \%$ are residents of Germany, coming mainly in tourist groups with cultural and educational purposes. Business travelers still are a small share in the total tourist flow. Among them, 18\% were foreign tourists, and 22\% - Russians.

In the first place Russian tourists visit the Kaliningrad region with health and leisure purpose (48 \%), which is combined with the cultural and educational tourism (28\%). Tourists are attracted by the opportunity to relax on 
the beach (34\%) (Ministry of Economy of the Kaliningrad region, 2014) Unfortunately, despite the unique natural-climatic and natural resources, the tourist flow in the region is still insufficient.

\subsection{Small Cross-Border Movement and Tourism Development}

It should be noted that in the Kaliningrad region at the present time, there is a common practice for foreign citizens (from Poland and Lithuania) to cross the border repeatedly (3-5 times a day) for buying excise goods (cigarettes, alcoholic beverages, gasoline). Ratification of the Agreement on small cross-border movement simplified crossing borders both for Russians - citizens of the Kaliningrad region and polish citizens. It had an impact on the frequency of the state border crossings and export (import) of the capital in the neighboring state. "In the period from January 1, 2013 to August 15, 2013, the customs service of the Kaliningrad region within the system of tax-free adopted 56722 fiscal cheque for the sum of about 65 million PLN (in 2010 these checks were 4484, and in 2012 - 40126)". Dominion Bureau of Statistics estimates for the first quarter of 2013 Russians coming to Poland within the framework of the Agreement on small cross-border movement spent 113.2 million PLN (an increase of 89,6\%, compared to the same period in 2012, when agreement not acted). The amount of money left by the polish citizens, going in the framework of the Agreement on small cross-border movement in the Kaliningrad region, is estimated at 96 million PLN (an increase of 95.5\%). In the second quarter of 2013 Russian citizens spent 124.8 million PLN (an increase of 54.8\%, compared with the same period in 2012, with no agreement), polish citizens in the region have spent 87,6 million PLN (increase by $47.2 \%$ ). This means that during the first half-year period of 2013 Russians left in Poland, at least 238 million PLN, and the polanders in Russia 143,2 million PLN. Significantly, the expenses incurred by the Russians during the first half-year period of 2013, amounted to $6,1 \%$ of total expenditures of foreigners in Poland and the costs of polanders visiting the Kaliningrad region was even $49 \%$ of the total expenditures of Polanders crossing polish land border (Dudzinska, 2013).

One of the factors limiting arrival of foreign tourists in the Kaliningrad region is a restriction for foreigners on movement within the Kaliningrad region, as there are border areas and territories with regulated entry.

The above mentioned limiting factors do not allow fully develop the hospitality industry of the Kaliningrad region. The most actively developing are regional center - Kaliningrad and local resorts Svetlogorsk and Zelenogradsk. These trends can be traced in the development of the hotel complex of the region: in these geographical areas the accommodation sector actively builds up hotels, guest houses and similar means of placement, though practically undeveloped in the periphery (Table 2).

Table 2. The accommodation sector in the Kaliningrad region

\begin{tabular}{ccc}
\hline Region member (Note 1) & $\begin{array}{c}\text { The number of hotels, guest houses and } \\
\text { similar accommodation facilities, units }\end{array}$ & Placements, units \\
\hline UD “City of Kaliningrad” & 43 & 3121 \\
MD Bagrationovsky & 2 & 77 \\
MD Polessky & 10 & 82 \\
MD Baltiysky & 7 & 303 \\
Pravdinsky District & 1 & 40 \\
Svetlogorsky District & 44 & 2656 \\
Gvardeysky District & 4 & 40 \\
MD Slavsky & 6 & 104 \\
UD Guryevsky & 9 & 462 \\
MD Chernyachovsky & 8 & 222 \\
UD Gusevsky & 6 & 159 \\
UD Ladushkinsky & 3 & 96 \\
Zelenogradsky District & 70 & 1714 \\
UD Mamonovsky & 2 & 49 \\
MD Krasnoznamensky & 7 & 117 \\
UD Pionersky & 2 & 66 \\
MD Nemansky & 4 & 101 \\
UD Svetlovsky & 2 & 48 \\
Nesterovsky District & 8 & 135 \\
UD Sovetsky & 5 & 542 \\
Ozersky District & 6 & 51 \\
UD Yantarny & 6 & $\ldots$ \\
Total & 255 & 10185 \\
\hline
\end{tabular}

Source: compiled by the authors 
The table shows that the market of accommodation looks quite unevenly in the territorial context: a leader in the number of hotels and similar accommodation facilities is Kaliningrad. Problem of the Kaliningrad hotel market is deficiency of any pronounced specific character of the accommodation facilities. They align their activities on different market segments (business travellers, tourists and members of tour groups etc). However, lately develops a tendency to open the hotels with extended range of services (hotels with entertainment centers, SPA-centers, business and congress-halls etc). Kaliningrad is followed by Svetlogorsk and Zelenogradsk. These resorts have a pronounced recreational specifics and located on the Baltic sea coast.

The negative aspect of the competitiveness of the Kaliningrad hotel business is the disparity of hotels and similar accommodation facilities with international standards. As of 01 June 2014 in the Kaliningrad region only 15 hotels and similar accommodation facilities were classified. Among them one 5-star hotel, one 4-star hotel, eight 3-star hotels. 5 accommodations classified into the category of "mini-hotel" on 3-star level (Baltic Status, 2014, p. 17).

\subsection{FIFA Requirements for the Hospitality Industry of the Kaliningrad Region}

Kaliningrad is one of the cities that will host the 2018 world Cup and in this regard, the hospitality industry of the region soon will be actively modernized and developed. This is due to the mandatory classification of accommodation facilities in accordance with order of the Ministry of culture from 03.12. 2012 and also with and requirements of FIFA. Thus, according to the requirements Kaliningrad should have 25 -star hotels for representatives of FIFA and VIP guests (100 and 50 rooms respectively), 24 -star hotels ( 80 rooms each) to accommodate participating teams. In addition, for the accommodation of accompanying guests (sponsors, business visitors) there should be 700 rooms available in at least 4-star hotels. Also it will be necessary to introduce to the market one or two hotels for the press and accredited journalists (at least 3-star level; not less than 200 rooms) and 5 hotels for other media representatives (capacity - 550 rooms). Besides that it is necessary to built campings and 2-star hotels with the capacity of 6000 places for fans. (Sazonova, 2014, p. 16).

All this shows that with the implementation of the above mentioned projects will increase competition on the hotel market of the Kaliningrad region dramatically. With a competent and properly developed strategy the hotel complex of the Kaliningrad region may become competitive on the market of the countries of the Baltic region and in the russian market of tourist services.

\section{Future Development of Competitive Hotel Complex of the Kaliningrad Region}

Hospitality industry, as mentioned before, is a promising and fast growing area of business. The Kaliningrad region has good potential for its development, however the neighborhood with well-developed, competitive territories - the Republic of Lithuania and the Republic of Poland - stimulates participants of the hotel market of the Kaliningrad region to develop actively. The government of the Kalinigrad region represented by the Minister of tourism is responsible for coordination and leadership of the hospitality of the region. Usually, the federal authorities, those in charge of the tourism development in different regions of the country, monitor the federal programs implementation. These authorities also engage in integrated planning of resourses, involved in the hospitality industry, develop the qualification requirements for the personnel, do regulatory framework etc. in conjunction with other ministries.

As one of the strategic objectives for the development of the Kaliningrad region, the formation of competitive hotel-tourist complex can be specified. Complex should meet the demand for accommodation services and accelerate development of the hotel complex of the region by means of budget revenues growth and also increase in the number of jobs, preservation and rational use of cultural and historical heritage. In the process of elaboration the strategic program for the development of the Kaliningrad hotel sector it must be taken into consideration that a large proportion of tourists (approximately $82 \%$ ) stops in the region for a short time. One aspect of strengthening the competitive position of participants in the hotel market and as a consequence the whole hotel complex of the region can become the narrow specialization of accommodation.

Summarizing all the above it should be said that the competitiveness of the hotel complex can be determined by competitive forces such as the value of the tourist potential of the region, the demand for accommodation services and its structure, scope and nature of its growth; availability of suppliers, related industries (intra-regional communications); level of competition in the domestic tourism market, the scope and prospects of growth in domestic tourism product; the price level; nature of the organization management in the sphere of tourism (policy, planning, marketing, etc.). Some of the above mentioned determinants are interdependant and complimentary. To achieve a high level of competitiveness in the accommodation sphere the Kaliningrad region needs a constant accumulation of benefits, the discovery and development of new segments, diversification of the tourist product and hotel services. To retain achieved competitive advantages, the quality of tourist services 
needs constant improvement, also needed introduction of modern information technologies, perfection of methods of marketing area, improving the quality of service and so on.

One of the factors of regional competitiveness the hospitality industry should be the introduction of new accommodation facilities various in level of comfort, but meeting the world standards. It includes also the hotel chains as indicator of investment attractiveness. Hotel complex of the Kaliningrad region is an attractive and profitable investment. In recent years as the result of increase of tourist the liquidity of investment in construction of hotels have increased. The attractiveness of investing in the construction of enterprises of hotel services is provided on one hand by the gradual consolidation of the image of the Kaliningrad region as the territory of the former East Prussia with the potential opportunities of development of tourism and attractive area for tourists from Russia on the other. Simultaneously to this, the reputation of the Kaliningrad region as virtually the only place in the world of mass production of amber, the unique Curonian spit, and most importantly the beneficial location (Kaliningrad region is the geographical center of Europe) - all this is the base and main precondition, if the necessary infrastructure is provided, for creating in Kaliningrad area attractive and competitive region.

\section{Reference}

Action report of the Governor of the Kaliningrad region. (2012). The Governor of the Kaliningrad region. Retrieved June 6, 2014, from https://www.gov39.ru/zip/otchet/gov39_2012.pdf

Blaug, M. (1994). The Economic Thought in Retrospect (4th ed.). Moscow, Russia: Delo Ltd.

Competitiveness Ranking Continues to Fall; Emerging Markets Are Closing the Gap. Weforum. Retrieved September 16, 2014, from www.weforum.org/news/us-competitiveness-ranking-continues-fall-emergingmarkets-are-closing-gap

Dolinskaya, M. G., \& Solovyev, I. A. (1991). Marketing and competitiveness of industrial products. Moscow, Russia.

Dudzinska, K., \& Dyner, A. (2013). Local border movement with the Kaliningrad region - challenges, opportunities and threats. Weforum. Retrieved August 10, 2014, from http://www.pism.pl/files/?id plik $=15092$

Hotels are forced to prove their "stardom". (2014). Baltic Status 6, 17.

Ministry of tourism of Kaliningrad region. Ministry of tourism of Kaliningrad region. Retrieved August 6, 2014, from http://tourism.gov39.ru/

On approval of the investment strategy of the Kaliningrad region for the period up to 2020: resolution of the Government of the Kaliningrad region. (2014). Ministry of Economy of the Kaliningrad region. Retrieved June 5, 2014, from http://investinkaliningrad.ru/wp-content/ uploads/2014/01/ invest_strategy.pdf

Porter, M. (1990). The Competitive Advantage of Nations. London: MacMillan.

Sazonova, O. (2014). How to attend 10 times more guests in 20 days. Baltic Status, 6, 14-16.

Semenova, L. V. (2006). Methodical features of enhancing the competitiveness of businesses organization in the region (Unpublished master's thesis). Kaliningrad state university, Kaliningrad.

Semenova, L. V., \& others (2013). Scientific-methodical approaches to the strategy elaboration of tourism development in the Kaliningrad region on the basis of cluster approach. Monograph. Kaliningrad: Edition Kant Baltic Federal University.

Smith, A. (1992). An Inquiry into the Nature and Causes of the Wealth of Nations (books 1-3). Moscow.

Socio-economic determinants of cross-border tourism on environmentally valuable areas. (2014). Greifswald-Szczecin.

Thatcher, M. (2003). Statecraft. Strategies for the changing world/translated from the English. Moscow

The report of the Governor of the Kaliningrad region N.N. Tsukanov on the activities of the Government of the Kaliningrad region for the year 2013, including on issues of the Kaliningrad regional Duma, and the message of the Governor of the Kaliningrad region N.N. Tsukanov about the main directions of its activity and the activity of the Government of the Kaliningrad region for 2014. Retrieved June 6, 2014, from http://gov39.ru/poslanie2014.php

Tourism in Pomerania in 2013. Gdansk.

Tourism in the Warmia-Mazury in 2013. Olsztyn. 
Tourism Trends and Marketing Strategies UNWTO. (2011). UNWTO. Retrieved September 2, 2014, from http://mkt.unwto.org/sites/all/files/docpdf/unwtohighlights11enhr_3.pdf

Zavyalov, P. (1995). Russian market through the eyes of a marketer. Russian economic journal, 7, 44-52.

\section{Note}

Note 1. MD - municipal district; UD - urban district; D - district.

\section{Copyrights}

Copyright for this article is retained by the author(s), with first publication rights granted to the journal.

This is an open-access article distributed under the terms and conditions of the Creative Commons Attribution license (http://creativecommons.org/licenses/by/3.0/). 